\title{
Volatilization of 1,3-Dichloropropene in Florida Plasticulture and Effects on Fall Squash Production
}

\author{
S.D. Nelson ${ }^{1}$ \\ U.S. Department of Agriculture, Agricultural Research Service, Crop Genetics and Environmental \\ Research Laboratory, P.O. Box 110965, Gainesville, FL 32611-0965
}

C. Riegel

Department of Entomology and Nematology, University of Florida, P.O. Box 110620, Gainesville, FL 32611

L.H. Allen, Jr. ${ }^{2}$

U.S. Department of Agriculture, Agricultural Research Service, Crop Genetics and Environmental Research Laboratory, P.O. Box 110965, Gainesville, FL 32611-0965

D.W. Dickson

Department of Entomology and Nematology, University of Florida, P.O. Box 110620, Gainesville, FL 32611

J. Gan

U.S. Department of Agriculture, Agricultural Research Service, U.S. Salinity Laboratory, 450 W. Big Springs Rd., Riverside, CA 92507-4617

S.J. Locascio

Department of Horticultural Sciences, University of Florida, P.O. Box 110690, Gainesville, FL 32611

D.J. Mitchell

Department of Plant Pathology, University of Florida, P.O. Box 110680, Gainesville, FL 32611

\begin{abstract}
AdDitional INDEX wORDs. 1,3-dichloropropene, Cucurbita pepo, soil fumigation, methyl bromide alternatives
Abstract. One of the proposed alternative chemicals for methyl bromide is 1,3-D. The most common forms of 1,3-D products are cis- or trans-isomers of 1,3-D with the fungicidal agent, chloropicrin, containing such mixtures as $65 \% 1,3-\mathrm{D}$ and $35 \%$ chloropicrin (C-35). Soil fumigants are commonly applied under a polyethylene film in Florida raised bed vegetable production. Much of the research regarding cropping system effects of alternative fumigants to methyl bromide has focused primarily on plant growth parameters, with little regard to the atmospheric fate of these chemicals. The objective of this research was to determine both the atmospheric emission of 1,3-D under different plastic film treatments and to evaluate effects of application rates of 1,3-D and C-35 on plant pests, growth, and yield of Sunex 9602 summer squash (Cucurbita pepo L.). Results showed that use of a high barrier polyethylene film (or virtually impermeable film - VIF) greatly reduced fumigant emission compared to ground cover with conventional polyethylene films or uncovered soil. Summer squash seedling survival was a severe problem in several of the 1,3-D alone treatments where no fungicidal agent was added, whereas C-35 resulted in excellent disease control at both full and one-half of the recommended application rates for this chemical. Both 1,3-D and C-35 provided good plant stands and higher yields when applied at their recommended application rates. However, all squash yields were lower than typical squash production levels due to late planting and early winter frost kill. Chemical names used: 1,3-dichloropropene (1,3-D); trichloronitropropene (chloropicrin).
\end{abstract}

The soil fumigant methyl bromide (MeBr) has been implicated as an ozone-depleting agent (Yagi et al., 1995; Yung, et al., 1980). $\mathrm{MeBr}$ is scheduled to be phased out of production for agricultural

Received for publication 23 June 2000. Accepted for publication 12 Mar. 2001 Florida Agricultural Experiment Station journal series R-07724. We thank Arthur Hornsby and John Thomas of the Dept. of Soil and Water Sciences, Univ. of Florida, Gainesville, for lending equipment necessary for collection of volatile gas samples. We also thank Wayne Wynn, Andy Frenock, Mike Alligood, and Tom Hewlett, U.S. Department of Agriculture, Agricultural Research Service (USDA/ARS) and Univ. of Florida employees, for technical assistance. We express gratitude to Jim Ralles (San Francisco, Calif.) and Klerk's Plastics (Hoogstraten, Belgium) for generous donation of Hytibar film. Mention of trade names or proprietary products is for the convenience of the reader only, and does not constitute endorsement or preferential treatment by USDA/ARS or the Univ. of Florida. The cost of publishing this paper was defrayed in part by the payment of page charges. Under postal regulations, this paper therefore must be hereby marked advertisement solely to indicate this fact.

'Present address: U.S. Department of Agriculture, Agricultural Research Service, Water Management Research Laboratory, 2021 S. Peach Ave., Fresno, CA 93727; e-mail shadnelson@usa.net.

${ }^{2}$ Corresponding author; e-mail lhajr@gnv.ifas.ufl.edu. fumigant use in the United States by the year 2005 due to its potential to deplete atmospheric ozone (USDA, 1999). An alternative compound, 1,3-D, is of importance because it is currently the foremost chemical replacement for $\mathrm{MeBr}$ (Locascio, et al., 1997; Schneider, et al., 1995). Although 1,3-D based compounds are not ozonedepleting, they are classified as toxic air substances due to their adverse toxicological effects as determined by the U.S. Environmental Protection Agency's Clean Air Act (USEPA, 1993).

The demand for 1,3-D to replace $\mathrm{MeBr}$, and the little time to properly study what influences $1,3-\mathrm{D}$ and $1,3-\mathrm{D}$ mixtures with $35 \%$ chloropicrin (C-35), will have on crop development, pest/pathogen management, and the environment make it imperative that studies regarding 1,3-D touch upon all these concerns. Of particular concern is the efficacy of 1,3-D based pesticides in controlling fungal diseases due to a long history of seedlings succumbing to these pathogens shortly after germination and emergence (Mitchell and Rayside, 1986). Much of the crop research performed on sandy soils does not address the impact of early fungal disease problems (Noling and Becker, 1994), such as seedling survival and damping 
off. This, in turn, can lead to lack of important information when evaluating a chemical's potential efficacy for adequately replacing other chemicals when dead seedlings are replaced by new seedlings or reseeded.

It has been reported that conventionally used polyethylene films are, in fact, permeable to $\mathrm{MeBr}$ (Yates, et al., 1996b). This poses a serious concern for long-term use of alternative soil fumigants, since lack of volatilization control after application may lead to atmospheric contamination and severe use restrictions. Use of alternative polyethylene films with much lower permeability than conventional polyethylene films may provide the means for retaining soil fumigants within the soil (Gamliel, et al., 1998; Wang and Yates, 1998). These film products are called virtually impermeable films (VIF), because they are only slightly permeable to soil fumigant gases. It has also been suggested that the amount of chemical needed for application may be reduced by as much as one-half because of the increased retention of the chemical within the soil by the VIF (Wang, et al., 1997).

A large portion of research regarding $\mathrm{MeBr}$ and 1,3-D has been conducted in laboratories to determine quantitatively the volatility of each compound and how to improve agricultural management practices to reduce atmospheric emission of these compounds (Gan, et al., 1998b; Trout and Ajwa, 1998). Although the vapor pressures of 1,3-D isomers are much lower than that of $\mathrm{MeBr}$ (34.3 and 23.0 $\mathrm{mm} \mathrm{Hg}$ for cis- and trans-1,3-D at $20^{\circ} \mathrm{C}$ ), they are still sufficiently high to result in significant atmospheric emissions (Gan et al., 1998a). Few studies have been performed regarding the fate of 1,3$\mathrm{D}$ in large-scale field studies to simulate an agricultural production scenario. Therefore, the objectives of this study were to 1) determine volatility of 1,3-D from bare, nontarped beds, and from VIF and polyethylene tarped beds, 2) evaluate efficacy of 1,3-D based compounds to control soilborne pests/pathogens, and 3) collect yield data on summer squash (Cucurbita pepo) to adequately describe the value of different chemical and film treatments.

\section{Materials and Methods}

Field SITE AND MEASUREMENT OF VOLATILIZATION. A field site consisting of Arredondo fine sand (loamy, siliceous, hyperthermic, Grossarenic Paleudult), a course-textured soil of low organic matter content $(\approx 1.0 \%)$, located at the Institute of Food and Agricultural Sciences' Green Acres research farm near Gainesville, Fla., was selected for the study. In the past, this field site had been cultivated repeatedly under spring and fall plantings of tomato (Lycopersicon esculentum Mill.), cucumber (Cucumis sativus L.), and squash for studies involving crop production alternatives to $\mathrm{MeBr}$.

The field site was prepared 9 Sept. 1999 by tilling the soil and $0.9-\mathrm{m}$ wide, $0.15-\mathrm{m}$ high beds were shaped into rows that were spaced $1.8 \mathrm{~m}$ apart on center. Beds were then fertilized using a drop spreader by applying $10 \mathrm{~N}-4.4 \mathrm{P}-8.3 \mathrm{~K}$ granular fertilizer at a rate of $800 \mathrm{~kg} \cdot \mathrm{ha}^{-1}$ and rototilling it into the top 0.3 $\mathrm{m}$ of the bed. Later, $\mathrm{N}$ at $16.5 \mathrm{~kg} \cdot \mathrm{ha}^{-1}$ in the form of $\mathrm{NH}_{4} \mathrm{NO}_{3}$ and $\mathrm{K}$ at $16.5 \mathrm{~kg} \cdot \mathrm{ha}^{-1}$ in the form of $\mathrm{KCl}$ was added six times in weekly applications through drip irrigation beginning 1 Oct. Calcium (in the form of $\mathrm{CaO}$ ) at the rate of $1.17 \mathrm{~L} \cdot \mathrm{ha}^{-1}$ was applied weekly beginning at flowering to reduce the incidence of blossom-end rot. Double-wall drip tubing (Chapin Twinwall, Watertown, N.Y.) with emitters spaced $0.3 \mathrm{~m}$ apart and a flow rate of $62 \mathrm{~mL} \cdot \mathrm{min}^{-1}$ per 30.5 m of row was placed about $0.1 \mathrm{~m}$ from the plant stems for application of water, fertilizer, and Ca. One honeybee (Apis nellifera L.) hive per 2.5 ha was placed near the fields at flowering to aid pollination (Hochmuth et al., 1998). The field layout consisted of a randomized complete block design consigned to six blocks with fifteen 12-m length beds in each plot. Outer rows were left untreated and served as buffer rows and the inner rows consisted of 13 completely randomized treatments.

The 13 treatments consisted of different film, fumigant, and chemical rate treatments. The film treatments included 1) a white over black (white/black) $0.025-\mathrm{mm}$ (1-mil) thick polyethylene plastic film, 2) a clear, 0.025-mm thick, Hytibar (Klerk's Plastics, Hoogstraten, Belgium) high barrier VIF, and 3) beds without polyethylene film (no film). The fumigants consisted of three treatments: 1) 1,3-D, 2) 1,3-D with 35\% chloropicrin (C-35), where chloropicrin is added as a antifungal agent, and 3) no fumigation.

Fig. 1. Portable above ground, polypropolene plastic air sampling chamber. Internal air and thermocouple shafts extended $0.1 \mathrm{~m}$ within the chamber to the approximate center for more accurate sample collection and readings from the external sampling ports. The open end of the chamber was placed on the plastic or bare soil and sealed around the edges by a weight on top of the chamber or with tape as appropriate to minimize wind disruption. Gas samples were withdrawn using a 50-mL syringe to collect 1,3-dichloropropene on ORBO-32 charcoal tubes.
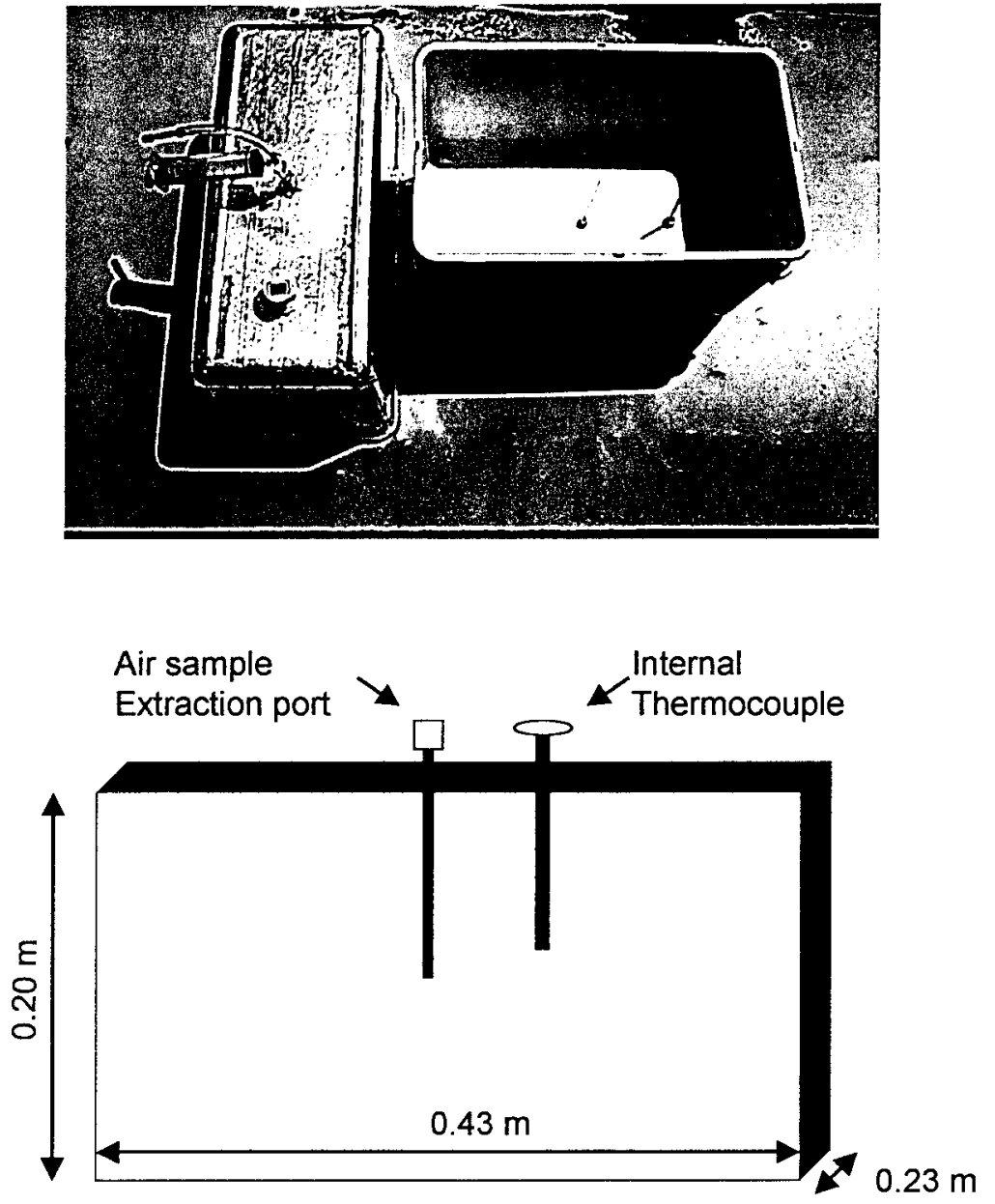

Chamber open at ground level for gas diffusion at soil/plastic interface 
The chemicals were consigned to three rates, full, one-half, and zero of the manufacturers recommended application rates. The C-35 chemical rate treatments were adjusted so that an equivalent amount of 1,3-D was applied to full and one-half rate treated rows of both 1,3-D and C-35 plots. The following film, fumigant, and chemical rate treatments were made: three check treatments-film $=$ no film, white/black, and VIF, fumigant = none; two treatments- film = no film, fumigant $=1,3-\mathrm{D}$, rates $=$ full and one-half; two treatmentsfilm $=$ white/black, fumigant $=1,3-\mathrm{D}$, rates $=$ full and one-half; two treatments- film $=$ VIF, fumigant $=1,3-\mathrm{D}$, rates $=$ full and one-half; two treatments- film $=$ white/black, fumigant $=\mathrm{C}-35$, rates $=$ full and one-half; and two treatments- film $=$ no film, fumigant $=\mathrm{C}-35$, rates $=$ full and one-half.

Application rates for 1,3-D were 160 and $80 \mathrm{~kg} \cdot \mathrm{ha}^{-1}$ and C-35 was applied at 275 and $138 \mathrm{~kg} \cdot \mathrm{ha}^{-1}$ to comprise the full and one-half recommended fumigation rates for these chemicals. Fumigants were chisel injected to a depth of $0.3-\mathrm{m}$ via three steel parachisels spaced 0.3-m away from the center chisel (Riegel et al., 2000). The parachisel was used to minimize chemical volatilization up the chisel shank by employing slanted steel chisels at a $45^{\circ}$ angle that leaves little if any chisel trace. The beds that required a film treatment were covered simultaneously with chemical injection, and soil was placed along the sides of the beds to hold the film in place and to minimize fumigant volatilization and excess chemical dissipation. No irrigation was applied to the field prior to or after fumigation to ensure that soil water content was below field capacity while maintaining proper soil porosity for chemical volatilization and diffusion. The fumigant was injected into the experimental plots during the afternoon of 9 Sept. 1999.

Atmospheric emission of 1,3-D was monitored 24, 48, or $72 \mathrm{~h}$ after fumigation on selected beds. The beds chosen for atmospheric sampling all were full rate 1,3-D treatments under white/black, VIF, and no film conditions. Concentration change with time of 1,3-D emitted from the beds was measured using open-bottom plastic chambers with reflective tape on the outside of the chamber to minimize temperature fluctuations. These rectangular chambers were made from high-density $0.01 \mathrm{~m}$ thick polypropylene plastic with dimensions of length, width, and height of $0.43,0.23$, and 0.20 $\mathrm{m}$, respectively. The inner chamber volume was $20 \mathrm{~L}$. Two access holes accommodated an airtight thermocouple and an airtight extraction tube to an inside depth of $0.1-\mathrm{m}$ from the top of the chamber (Fig. 1). The open side of the chamber was placed over the soil or mulch surface, and tape was used to seal the chamber to the films on the final sampling date due to minor wind movement. Winds were moderate during measurements with average wind movement being $0.8 \mathrm{~m} \cdot \mathrm{s}^{-1}$ for 10 and 11 Sept., respectively, and 1.1 $\mathrm{m} \cdot \mathrm{s}^{-1}$ on 12 Sept. Large tent umbrellas were placed over the chambers to provide shade during the 2.5 -h sampling period. The inner chamber thermocouples were monitored to assure that the temperature was maintained near that of ambient. Chamber temperatures for the three sampling days were between 32 and $37^{\circ} \mathrm{C}$.

A total of $0.1 \mathrm{~L}$ air volume was extracted from the chambers and collected onto charcoal filter sampling tubes (ORBO-32, Supelco Inc., Bellefonte, Pa.). Extracted air samples were 1/200 of the chamber volume and were withdrawn slowly to prevent higher concentration gradients across the soil/plastic/atmosphere interface. Chamber air samples were extracted $0,0.25,0.5,1.0,2.0$, or 2.5 $\mathrm{h}$ after initial placement of the chamber over the treated bed. Immediately after sample extraction, the tubes were capped and placed on dry ice in the field and transferred to $\mathrm{a}-86^{\circ} \mathrm{C}$ freezer for later analysis. Analysis of 1,3-D volatilization was performed by gas chromatography (GC) after solvent extraction. Charcoal granules were pushed into 8.7-mL headspace vials, and $4 \mathrm{~mL}$ of acetone was added. Vials were capped, shaken for $1 \mathrm{~h}$, then a fraction of the sample was transferred into GC vials for analysis. Analysis was performed on a HP6890 gas chromatograph (Hewlett Packard, San Francisco, Calif.). with an electron capture detector, and an Rtx-624 capillary column $(30 \mathrm{~m} \times 0.32 \mathrm{~mm} \times 1.4 \mathrm{~mm})$. Inlet temperature was $220^{\circ} \mathrm{C}$, detector temperature $300^{\circ} \mathrm{C}$, and oven temperature held at $50^{\circ} \mathrm{C}$ for $2 \mathrm{~min}$, ramped to a temperature of $140^{\circ} \mathrm{C}$ at $15^{\circ} \mathrm{C} \cdot \mathrm{min}^{-1}$, and held at $140^{\circ} \mathrm{C}$ for $2 \mathrm{~min}$. Calibration was made with 1,3-D standard composed of $48 \%$ cis and $49 \%$ trans isomers, purchased from Chem Serv., Inc., West Chester, Pa.

Soil atmosphere probe samplers were constructed from $0.5-\mathrm{m}$ long, 3.2-mm diameter copper tubing, connected to a $20-\mathrm{mL}$ inverted glass vial placed in the center of the bed at a depth of $0.3 \mathrm{~m}$. Excess copper tubing outside of the bed was laid along the bed and under the plastic where necessary, and Swage-lock, fittings (Niagara valve and fitting Ltd., Hamilton, Ontario) with Thermo-green, septa (Supelco Inc., Bellefonte, $\mathrm{Pa}$ ) were fitted to the ends of the copper tubing. Soil atmosphere samples were taken 1, 2, or $3 \mathrm{~d}$ after fumigation and samples replicated three times throughout the $2.5 \mathrm{~h}$ chamber sampling period. Soil atmosphere samples were taken using a 50-mL syringe and, after pulling the sample from the Swagelock fitting, immediately injecting the sample onto charcoal filter tubes and storing them over dry ice.

Thermocouples were placed to a depth of $0.05,0.15$, and $0.25 \mathrm{~m}$ from the bed surface to monitor soil temperature differences caused by the various film treatments. Gan et al. (1999) found that 1,3-D chemical degradation in sandy soil types followed the Arrhenius equation, but microbial degradation had only a small role between 20 to $40^{\circ} \mathrm{C}$ and then was completely inhibited beyond $40{ }^{\circ} \mathrm{C}$. Due to the fall climatic conditions, soil temperatures were relatively consistent throughout the sampling period with cooler temperatures deeper down the soil profile. Temperature, solar radiation, and relative humidity data were monitored to minimize any potential problems associated with charcoal tube collection techniques (Nelson et al., 1976).

FiEld STUdies. On 1 Oct. 1999, 'Sunex 9602' hybrid summer squash seeds were sown by hand at a spacing of $0.45-\mathrm{m}$ along the length of the bed. For insect and fungal control, the following chemicals were sprayed on plants every 7 to $10 \mathrm{~d}$ after planting: Lannate, LV (DuPont, Inc., LaPorte, Texas) with 29\% methomyl (S-methyl-N-[methyl-carbamoyl]oxy)-thioacetimide at $1.75 \mathrm{~L} \cdot \mathrm{ha}^{-1}$ and Bravo, Weather Stik (Zeneca Ag Products Inc., Calgary, Alberta) with $54 \%$ chlorothalonil (tetrachloroisophthalonitrile) also at 1.75 $\mathrm{L} \cdot \mathrm{ha}^{-1}$

Summer squash was harvested 22, 24, 26, and 29 Nov. and 1 Dec., before a killing frost occurred on 2 Dec. 1999. A total of 12 plants per bed were dug and roots were rated for root-knot nematode [(Meloidogyne incognita (Kofoid and White) Chitwood)] galling. Nematode root gall rating was performed using a grading scale of 0 to 10 , with $0=$ no galls, $1=1 \%$ to $10 \%$ root system galled, $2=11 \%$ to $20 \%$ galled, ...through $10=100 \%$ of root system galled (Barker, 1985). Plant growth of each bed treatment was visually rated for plant vigor (on a scale of 1 to $10,1=$ very poor, and $10=$ excellent plant growth) and after harvest the shoots of 12 plants were collected, bagged, and dried at $60{ }^{\circ} \mathrm{C}$ for $7 \mathrm{~d}$ and weighed.

On 2Dec. 1999, immediately following the removal of plants, 12 soil cores per bed treatment were taken to a depth of $0.15 \mathrm{~m}$ where the plants were dug, stored in plastic bags, and taken to the lab for soilborne fungal pathogen analysis by an agar plating method (Locasio et al., 1999; Mitchell and Rayside, 1986). Samples were replicated three times at different field locations for each treatment sampled. 
Data analyses. The various biological response data were subjected to analysis of variance (ANOVA) procedures using general linear model procedures of SAS (SAS Inst. Inc., Cary, N.C.) and means were separated by Duncan's multiple range test (Freund and Littell, 1981). Procedures were executed using SAS for personal computers, version 6.12. Analysis of data by ANOVA for the film variable and film $\times$ rate interaction were found to be nonsignificant; therefore, the data set was reanalyzed without the inclusion of the film effect and these results are reported. The 1,3-D efflux densities were determined by the time rate-of-change of concentrations of 1,3-D collected in each chamber during the sampling period. Means and SEs of both 1,3-D efflux densities and soil gas concentrations were computed.

\section{Results and Discussion}

Volitalization of 1,3-D. At $24 \mathrm{~h}$ after fumigant injection, efflux densities of both cis-and trans-isomers of 1,3-D were about 3 times greater from beds with the no film treatment than from the VIF treatment, and about 2 times greater for the white over black (white/ black) polyethylene film treatment than for the VIF treatment (Fig. 2 ). The greatest continual volatilization of both cis- and transisomers of 1,3-D throughout the $3 \mathrm{~d}$ period following fumigation
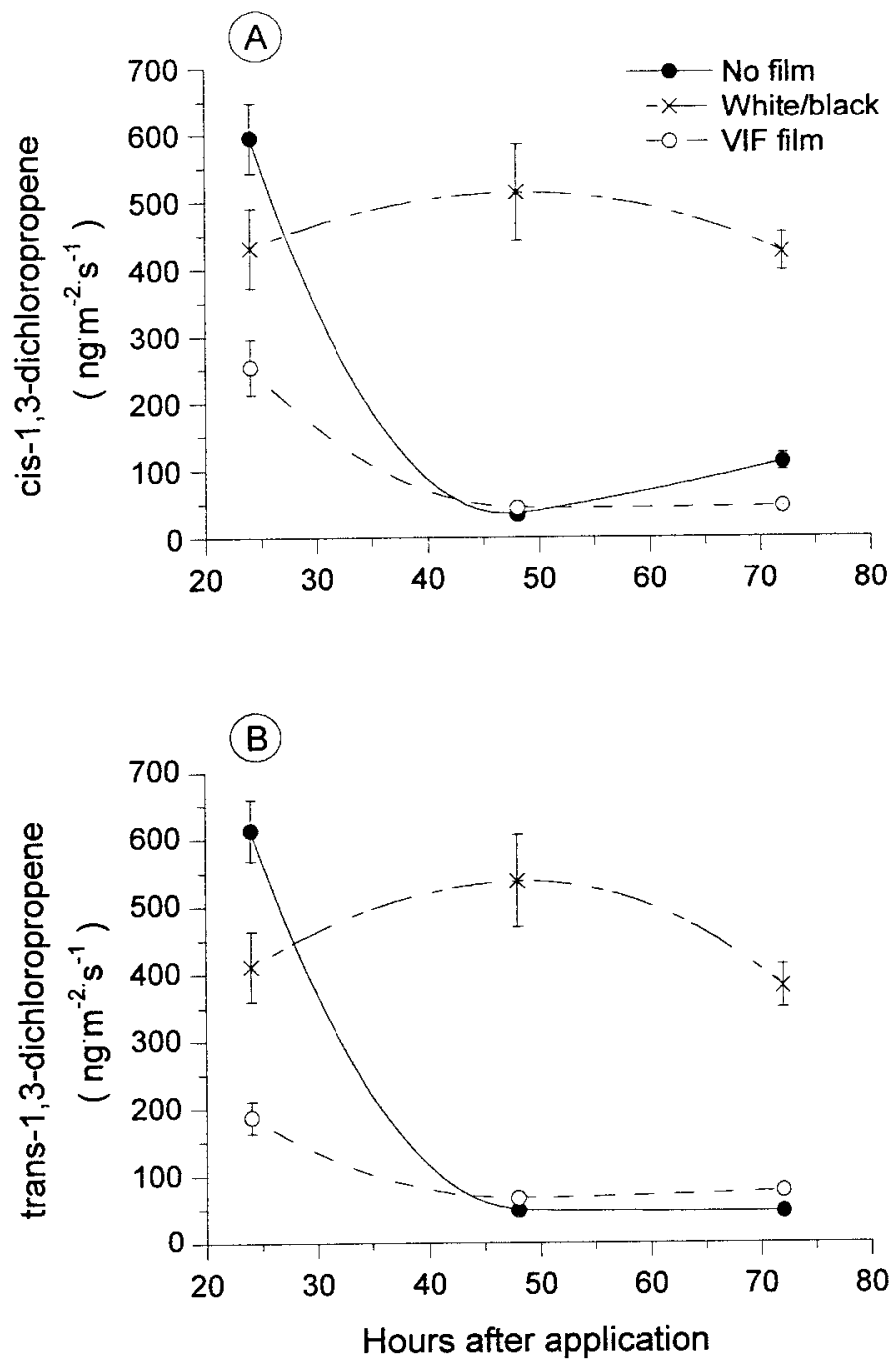

Fig. 2. Volatilized flux of the (A) cis- and (B) trans-isomers of 1,3-D emitted through the bed surface measured for $3 \mathrm{~d}$ after chemical injection into the soil. Vertical bars $=$ SE $(n=5)$. was from beds covered with white/black polyethylene film. This conventional polyethylene plastic appeared to be permeable to 1,3$\mathrm{D}$ as has been demonstrated earlier for MeBr (Wang et al., 1997). Although the film acted as a barrier to rapid initial gas release, it did not prevent the continual emission of 1,3-D into the atmosphere. Although the absence of any film showed the highest volatilization rates during the initial sampling, subsequent volatilization was very low, probably due to the rapid early losses from the soil surface. Thus, lack of film diminished retention, and possibly decreased efficacy, of applied 1,3-D. Peak release of 1,3-D in all the treatments most likely occurred within the first $24 \mathrm{~h}$ after fumigant application. In controlled laboratory columns, 1,3-D emissions were detected within $7 \mathrm{~h}$ after fumigation (Gan et al., 1998b) and peaked before 24 $\mathrm{h}$ after application of fumigant (Gan et al., 2000). The sample collection in this study did not begin until $24 \mathrm{~h}$ after application (Fig. 2). This sampling procedure unfortunately precluded the calculation of an appropriate mass balance, or the time or intensity of maximum efflux density. Generally, most volatilization occurs during the first $5 \mathrm{~d}$ following fumigation (Gan et al., 1998b; Majewski et al., 1995).

Efflux densities of 1,3-D were low for both the no film and the VIF treatments at 48 and $72 \mathrm{~h}$ after application (Fig. 2). However, the reasons for these low observed emissions for these two treatments are likely to be quite different. For the no film treatment, the large 1,3-D efflux density at $24 \mathrm{~h}$ after application followed by a sharp decrease by $48 \mathrm{~h}$ after application indicated that most of the volatilization likely occurred within the first $48 \mathrm{~h}$ after fumigation. Since most emissions apparently occurred within $2 \mathrm{~d}$ after application, less time would be available for soil disinfestations and more chemical would escape to the atmosphere. For the VIF covered beds, the low emissions throughout the sampling periods implies a greater retention of 1,3-D in the soil. Thus, this treatment shows promise of decreasing chemical loss and thereby providing a greater retention time for potential chemical efficacy and eventual soilderived degradation rather than emission to the atmospheric environment.

The concentration of 1,3-D in the soil atmosphere, taken simultaneously during the above-ground efflux sampling period, is shown in Fig. 3. The soil air data confirmed the findings from the above ground efflux density measurements, since the treatments with the highest initial emissions from the beds had the lowest soil air 1,3-D concentration throughout the measurement period. This opposite relationship would be expected since higher emission

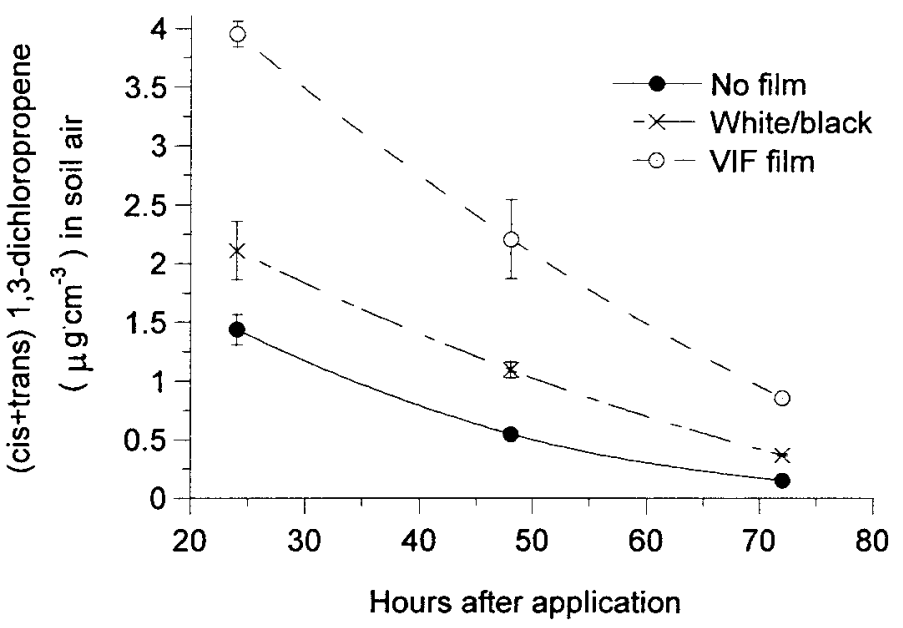

Fig. 3. Average soil atmosphere concentration of 1,3-D located $30 \mathrm{~cm}$ under the center of the bed surface. Samples were collected every morning for the space of $4 \mathrm{~d}$ after chemical injection into the soil. Vertical bars $=\mathrm{SE}(\mathrm{n}=5)$. 


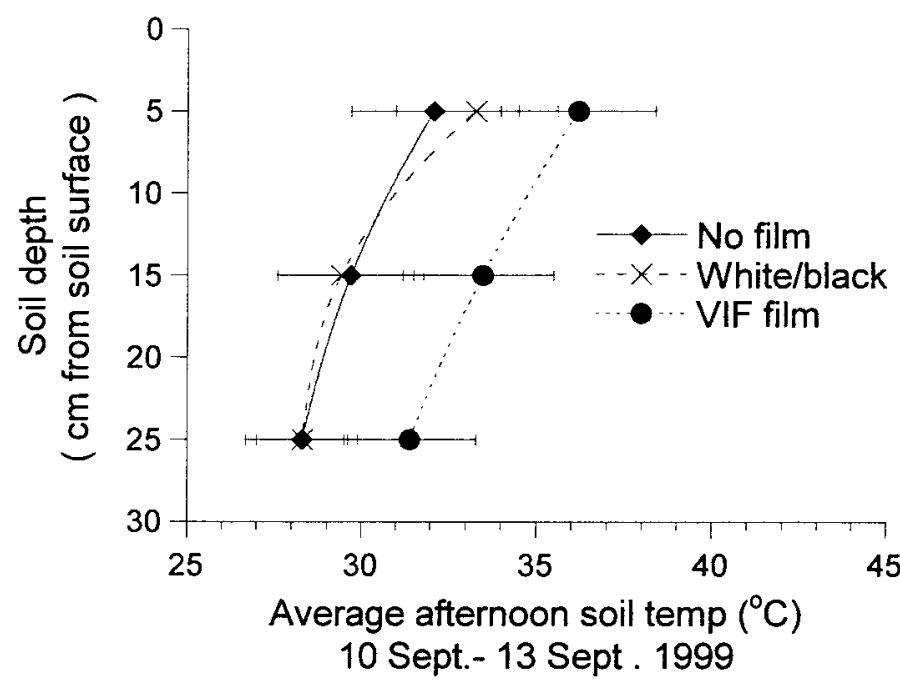

Fig. 4. Average daytime soil temperatures for 10 Sept. to 13 Sept. 1999 taken at three depths underneath raised-beds covered with white over black (white/ black) polyethylene film, clear virtually gas impermeable film (VIF), and beds without a film cover (no film). Horizontal bars $=S D(n=9)$ for temperatures taken three times during each sampling period.

would result in lower subsurface gas retention. The VIF had soil air concentrations of 1,3-D twice that of white/black film treated beds. The white/black polyethylene film treatments were at least $50 \%$ higher in soil air concentration than beds without film covers, which shows the ability of this film to retain some $1,3-\mathrm{D}$, probably by suppressing turbulent transport in the air near the soil surface. It is apparent from Fig. 3 that within the initial $24 \mathrm{~h}$ after fumigation that the no film treatment lost the most 1,3-D to volatilization, followed by white/black film, and then VIF as observed by their soil air concentrations $24 \mathrm{~h}$ after 1,3-D application. The continuous decrease in 1,3-D concentration in the VIF (Fig. 3) would suggest that the VIF is slightly permeable to $1,3-\mathrm{D}$, and/or potential lateral chemical movement under the bed led to emissions through the uncovered row middles. Nevertheless, the amount of gas released was substantially reduced in the VIF compared to both uncovered and polyethylene covered beds.

Pesticide degradation in soil is dependent upon soil temperature and plastic films can result in elevated soil surface temperatures (Yates et al., 1996a). In a laboratory experiment, degradation of cisand trans-1,3-D is increased 5.2 and 7.1 times, respectively, as temperature increased from 20 to $50^{\circ} \mathrm{C}$ (Gan et al., 1999). The VIF used in this study caused higher soil surface temperatures during the day. The VIF was clear which allowed more penetration of solar radiation to the soil surface and retention of entrapped long wave radiation compared to the white/black or no film treatments (Chase et al., 1999). The average soil temperatures taken during the 2.5-h gas sampling periods are shown in Fig. 4. Although differences between temperature means were not significant, the average temperature at the $0.05-\mathrm{m}$ depth under white/black polyethylene film was slightly higher than with no film, whereas clear VIF had temperatures 3 to $5^{\circ} \mathrm{C}$ higher than the other treatments at all depths. However, the shift in average temperature data is informative as White/black plastic film is slightly higher that no film at the $5 \mathrm{~cm}$ depth, while clear VIF had temperatures 3 to $5{ }^{\circ} \mathrm{C}$ higher at all depths. Temperature differences would have been greater if this experiment had been performed during summer months. The final point to make is that, even with the higher temperature, which should accelerate chemical and biological degradation rates in the VIF treatment as compared to the others, the VIF still resulted in the greatest 1,3-D retention and lowest 1,3-D emission. This suggests that incorporation of VIF into plasticulture management practice may be a sound alternative to conventional polyethylene films for reducing fumigant emissions to the atmosphere and for increasing soil retention time which can improve chemical efficacy and diminish environmental impact through biological degradation in the soil.

Nematode GALLING INDICES. All plots had a relatively low percentage of roots infested with root-knot nematodes (Table 1). The most effective nematode control occurred in plots fumigated at the full C-35 application rate, with only $2 \%$ of the squash root system galled. The one-half rate of C-35 was not statistically different in its control of nematodes from the full-rates of C-35 and 1,3-D that had $5 \%$ and $6 \%$ galling, respectively. The one-half rate $1,3-\mathrm{D}$ treatment had $12 \%$ of roots galled, and the nonfumigated plots had $14 \%$ of roots galled. This indicates that root-knot nematode problems were not a severe concern in this study possibly due to the late planting date or field history of annual fumigation. However, the data are still useful to supply plausible estimates for future root-knot nematode control by these chemicals and application rates.

FunGAL SUPPRESSION. A major factor influencing plant survival can be the degree of fungal disease control. Lack of Pythium sp. (damping off) control can be a devastating factor in achieving plant establishment and a healthy plant stand. Visually, some treatments appeared better than others after seedling emergence and the early stages of plant development. Although measurements of early season Pythium sp. were not obtained at the end of the growing

Table 1. Root-knot nematode (RKN) galling indices and soilborne Pythium irregulare (Bruisman) and other fungal propagules following soil fumigation and growth of 'Sunex 9602' summer squash during Fall 1999 at the University of Florida Green Acres Research Farm west of Gainesville, Fla.

\begin{tabular}{|c|c|c|c|c|}
\hline \multirow[b]{2}{*}{$\begin{array}{l}\text { Soil } \\
\text { fumigant }^{2}\end{array}$} & \multirow[b]{2}{*}{$\begin{array}{l}\text { Applied rate } \\
\left(\mathrm{kg} \cdot \mathrm{ha}^{-1}\right)^{\mathrm{y}}\end{array}$} & \multirow[b]{2}{*}{$\begin{array}{l}\text { RKN galling } \\
\text { index }^{x}\end{array}$} & \multicolumn{2}{|c|}{ Soilborne pathogens } \\
\hline & & & $\begin{array}{c}\text { P. irregulare } \\
\text { (propagules/kg) }\end{array}$ & $\begin{array}{c}\text { Others } \\
\text { (propagules } / \mathrm{kg} \text { ) }\end{array}$ \\
\hline None & 0 & $1.4 \mathrm{a}^{\mathrm{w}}$ & $5,000 \mathrm{a}$ & $30,000 \mathrm{a}$ \\
\hline $1,3-\mathrm{D}$ & 80 & $1.2 \mathrm{ab}$ & $3,000 \mathrm{a}$ & $22,000 \mathrm{ab}$ \\
\hline $1,3-\mathrm{D}$ & 160 & $0.6 \mathrm{~b}$ & $2,000 \mathrm{ab}$ & $10,000 \mathrm{ab}$ \\
\hline $\mathrm{C}-35$ & 138 & $0.5 \mathrm{bc}$ & $0 \mathrm{~b}$ & $0 \mathrm{~b}$ \\
\hline C-35 & 275 & $0.2 \mathrm{c}$ & $0 \mathrm{~b}$ & $0 \mathrm{~b}$ \\
\hline
\end{tabular}

${ }^{\mathrm{z}} 1,3-\mathrm{D}=1,3$-dichloropropene and $\mathrm{C}-35=1,3-\mathrm{D}+35 \%$ chloropicrin.

y1,3-dichloropropene rates were adjusted so that equal amounts of 1,3-D were applied to the one-half recommended application rate for summer squash and equivalent amounts of 1,3-D for the full recommended application rate.

${ }^{\mathrm{x}}$ Gall Index based on 1 to 10 rating, where $0=$ no galls, $1=10 \%$ root system galled, $2=11 \%$ to $20 \%, \ldots$ through $10=100 \%$ galled root system.

wMean separation $(\mathrm{n}=3)$ within columns by Duncan's multiple range test, $P=0.05$. 
Table 2. Growth and survival ratings of 'Sunex 9602' summer squash grown following fall soil fumigation at the University of Florida Green Acres Research Farm west of Gainesville, Fla.

\begin{tabular}{|c|c|c|c|c|}
\hline $\begin{array}{l}\text { Soil } \\
\text { fumigant }^{2}\end{array}$ & $\begin{array}{c}\text { Applied rate } \\
\left(\mathrm{kg} \cdot \mathrm{ha}^{-1}\right)^{\mathrm{y}}\end{array}$ & $\begin{array}{c}\text { Plant survival } \\
(\%)\end{array}$ & $\begin{array}{l}\text { Plant growth } \\
\text { visual rating }\end{array}$ & $\begin{array}{c}\text { Shoot dry wt } \\
\left(\mathrm{kg} \cdot \mathrm{ha}^{-1}\right)\end{array}$ \\
\hline None & 0 & $69 \mathrm{~b}^{\mathrm{W}}$ & $2.8 \mathrm{c}$ & $76 \mathrm{c}$ \\
\hline $1,3-\mathrm{D}$ & 80 & $78 \mathrm{ab}$ & $3.4 \mathrm{c}$ & $86 \mathrm{c}$ \\
\hline $1,3-\mathrm{D}$ & 160 & $93 \mathrm{a}$ & $4.9 \mathrm{~b}$ & $163 \mathrm{~b}$ \\
\hline C-35 & 138 & $82 \mathrm{ab}$ & $3.8 \mathrm{bc}$ & $108 \mathrm{bc}$ \\
\hline $\mathrm{C}-35$ & 275 & $79 a b$ & $6.8 \mathrm{a}$ & $231 \mathrm{a}$ \\
\hline
\end{tabular}

${ }^{\mathrm{z}} 1,3-\mathrm{D}=1,3$-dichloropropene and $\mathrm{C}-35=1,3-\mathrm{D}+35 \%$ chloropicrin.

$\mathrm{y}_{1,3}$-dichloropropene rates were adjusted so that equal amounts of 1,3-D were applied to the one-half recommended application rate for summer squash and equivalent amounts of 1,3-D for the full recommended application rate.

${ }^{\mathrm{x}}$ Visual summer squash visual index on plant growth health, where $1=$ very poor, $\ldots$ through $10=$ excellent.

${ }^{w}$ Mean separation $(\mathrm{n}=6)$ within columns by Duncan's multiple range test, $P=0.05$.

Table 3. Total number of fruit harvested, mean fruit weight, and total fruit yield of 'Sunex 9602' summer squash following fall soil fumigation at the University of Florida Green Acres Research Farm west of Gainesville, Fla.

\begin{tabular}{|c|c|c|c|c|}
\hline $\begin{array}{l}\text { Soil } \\
\text { fumigant }^{2}\end{array}$ & $\begin{array}{l}\text { Applied rate } \\
\left(\mathrm{kg} \cdot \mathrm{ha}^{-1}\right)^{\mathrm{Yy}}\end{array}$ & $\begin{array}{l}\text { Squash harvest } \\
\text { (fruit } / \mathrm{m})\end{array}$ & $\begin{array}{l}\text { Fruit wt } \\
\qquad(\mathrm{g})\end{array}$ & $\begin{array}{l}\text { Total yield } \\
\left(\mathrm{t} \cdot \mathrm{ha}^{-1}\right)\end{array}$ \\
\hline None & 0 & $7.9 \mathrm{c}^{\mathrm{x}}$ & $73 \mathrm{~b}$ & $0.70 \mathrm{C}$ \\
\hline $1,3-\mathrm{D}$ & 80 & $8.6 \mathrm{bc}$ & $87 \mathrm{ab}$ & $0.87 \mathrm{bc}$ \\
\hline $1,3-\mathrm{D}$ & 160 & $13.2 \mathrm{ab}$ & $101 \mathrm{a}$ & $1.34 \mathrm{ab}$ \\
\hline $\mathrm{C}-35$ & 138 & $11.1 \mathrm{abc}$ & $90 \mathrm{ab}$ & $1.08 \mathrm{bc}$ \\
\hline C-35 & 275 & $15.6 \mathrm{a}$ & $94 a b$ & $1.78 \mathrm{a}$ \\
\hline
\end{tabular}

${ }^{\mathrm{z}} 1,3-\mathrm{D}=1,3$-dichloropropene and $\mathrm{C}-35=1,3-\mathrm{D}+35 \%$ chloropicrin.

y1,3-dichloropropene rates were adjusted so that equal amounts of 1,3-D were applied to the one-half recommended application rate for summer squash and equivalent amounts of 1,3-D for the full recommended application rate.

${ }^{x}$ Mean separation $(n=6)$ within columns by Duncan's multiple range test, $P=0.05$.

season, soil samples from a subset of treatments were analyzed for fungal diseases and Pythium sp. were found in several of the treatments (Table 1). Control of $P$. irregulare (Buisman) was excellent with C-35 at both the one-half and full application rates with no propagules found. This was not the case for the one-half rate 1,3-D and nonfumigated treatments that led to poor $P$. irregulare control. The full rate of 1,3-D treatment was not significantly different than C-35 treatments at the 95\% confidence level. Poor suppression of soilborne fungi was also found in the 1,3-D and nonfumigated plots with propagules exceeding 30,000 propagules $/ \mathrm{kg}$ soil. As expected, higher chemical rates led to better fungal control. The nonfumigated plots had the highest counts of soilborne fungi propagules, followed by 1,3-D treated plots with decreasing propagule counts as 1,3-D fumigant rates increased. These fungal disease levels are high enough to cause significant damage to young seedlings, reduce plant growth, and limit crop maturation. No soilborne fungi propagules were found in the C-35 treated plots, reconfirming that the antifungal agent chloropicrin performed well. It is apparent from these data that adequate fungal and nematode control can be accomplished with a lower application rate of 1,3-D when combined with chloropicrin. Differences in fungal suppression between all treatments led to significant differences in summer squash plant growth and marketable fruit yield.

Plant growth AND Yield. Plant growth was monitored visually on a rating scale of 1 to 10 , with 10 representing excellent plant growth (Table 2). A visual rating of plant growth provides a numerical index to judge how well the plants grew in comparison to a fully lush vegetative summer squash plant. The highest plant growth rating was observed at the full-rate of C-35, followed by the full-rate of 1,3-D. The one-half application rates of C-35 and 1,3-D performed statistically equivalent to each other, while the poorest performance was observed from the nonfumigated treatments. From the plant survival measurements alone it appears that all chemical treatments resulted in similar plant survival rates. However, the rating of plant growth was drastically different with the most healthy plants occurring at the full application rates, followed by the large differences between one-half rate and nonfumigated treatments. The effects of these differences are reflected in shoot dry weight (DW) taken after the final harvest event (Table 2). Shoot DWs of all treatments were statistically similar to that of the visual plant ratings. Results obtained with the one-half 1,3-D and C-35 application rates indicate that adequate plant growth and pest control may not be achievable at these rates.

Yield is often the best determinant of chemical efficacy in the field (Table 3). The greatest harvest of squash was from the C-35 full-rate plots, followed by the full-rate of 1,3-D. The number of fruit harvested from the full-rate treatments was 1.6 to 2.0 times greater than that harvested from the nonfumigated treatments. The one-half-rate treatments did not provide statistically greater squash harvest counts than the nonfumigated plots. The average weight of harvested summer squash was relatively equivalent in all treatments. Only the full-rate 1,3-D treatment had a significantly greater fruit weight than the nonfumigated treatment. Finally, total crop yield was highest in the full-rate C-35 treated plots with summer squash yields 2.5 times greater than that of the nonfumigated plots. No statistical differences in yield were found between full-rate C-35 and 1,3-D treatments. However, the total yield values for each treatment were low in comparison to typical summer squash yields. The low yields were most likely due to an overall low number of fruit harvested per treatment, growth during cooler fall temperatures, and an early killing frost within 2 weeks of the beginning of marketable fruit production. 


\section{Summary}

Evaluation of 1,3-D in the present study as a potential replacement for MeBr suggests this fumigant will be more effective when combined with an antifungal agent such as chloropicrin. Complete control of soilborne fungi and Pythium sp. was achieved with onehalf and full recommended application rates of C-35. Equivalent injection rates of 1,3-D alone did not provide complete control of these fungi, although fungal pest control with the full rate of 1,3-D was not statistically different from that of the C-35 treatments. Fungal control for nontreated soil was poor and statistically less effective than that with soil treated with C-35. These fungal data were collected at the end of the growing season rather than at the beginning, they still indicate likely reasons for lowered plant stand development, shoot growth, and fruit yield between treatments.

This study demonstrates that significant reductions in yield may occur if soil fumigant rates are reduced well below the current recommended application rate. Reducing the application rate of 1,3D by one-half led to significantly lower plant growth visual rating, shoot DW, number of squash fruit harvested, and total yield, compared to a full-rate of C-35. Also, the one-half rate C-35 treatment was lower in plant growth visual rating, shoot DW, and total yield, than the full-rate C-35 treatment, but was not statistically different in other harvest parameters. No statistical differences in the final harvest data were found between C-35 and 1,3-D full-rate treatments, even though the $\mathrm{C}-35$ treatment had significantly greater shoot DW and plant growth visual rating, which might have led to other significant differences had the crop not been interrupted by an early frost. These data indicate that chemical application rates will most likely have to exceed one-half the recommended rate. Unfortunately, the film effect was not statistically significant alone or interactions of film $\times$ rate to draw further comparisons with the 1,3$\mathrm{D}$ volatilization emissions data, and due to a limited number of chambers, only the recommended full application rate of 1,3-D was collected and analyzed.

Use of VIF for volatile fumigants is promising since it resulted in lower atmospheric emissions and greater soil air concentrations of 1,3-D compared to polyethylene or no film treatments. Conventional polyethylene films may not be an adequate plasticulture. These plastics are permeable to fumigant gases and do not provide sufficient retention to prevent excessive emissions or adequate time for most of the fumigant to degrade in the soil. Agricultural managers need to adopt new plasticulture materials and different cultural practices to prevent excess chemical volatilization and thereby avoid further restrictions on use of 1,3-D as an alternative replacement for MeBr. Further research is needed to determine acceptable lower chemical application rates under VIF, which might offset the increased cost of VIF compared to conventional film use.

\section{Literature Cited}

Barker, K.R. 1985. Nematode extraction and bioassays, p. 19-35. In: K.R. Barker, C.C. Carter, and J.N. Sasser (eds.). An advanced treatise on meloidogyne. vol. II. Methodology. U.S. Agency Intl. Dev., Raleigh, N.C.

Chase, C.A., T.A. Sinclair, D.O. Chellemi, S.M. Olson, J.P. Gilreath, and S.J. Locascio. 1999. Heat-retentive films for increasing soil temperatures during solarization in a humid, cloudy environment. HortScience. 34:1085-1089.

Freund, R.J. and R.C. Littell. 1981. SAS for linear models. SAS Inst., Inc., Cary, N.C.

Gamliel, A., A. Grinstein, L. Klien, Y. Cohen, and J. Katan. 1998. Permeability of plastic films to methyl bromide: Field study. Crop Protection 17:241-248.

Gan, J., C. Hutchinson, F.F. Ernst, J.O. Becker, and S.R. Yates. 2000. Column system for concurrent assessment of emission potential and pest control of soil fumigants. J. Environ. Quality 29:657:661.

Gan, J., S.K. Papiernik, S.R. Yates, and W.A. Jury. 1999. Temperature and moisture effects on fumigant degradation in soil. J. Environ. Quality 28:14361441.

Gan, J., S.R. Yates, D. Crowley, and J.O. Becker. 1998a. Acceleration of 1,3Dichloropropene degradation by Organic Amendments and Potential Application for Emissions Reduction. J. Environ. Quality 27:408-414.

Gan, J., S.R. Yates, D. Wang, and F.F. Ernst. 1998b. Effect of application methods on 1,3-dichloropropene volatilization from soil under controlled conditions. J. Environ. Quality 27:432-438.

Hochmuth, G.N., D.N. Maynard, C.S. Vavrina, W.M. Stall, T.A. Kucharek, P.A. Stansly, T.G. Taylor, S.A. Smith, and S.A. Smajstrla. 1998. Curcubit production in Florida, p. 137-152. In: G.J. Hochmuth and D.N. Maynard (eds.). Vegetable production guide for Florida, SP 170. Univ. of Fla., Gainesville, Coop. Ext. Serv.

Locascio, S.J., J.P. Gilreath, D.W. Dickson, T.A. Kucharek, J.P. Jones, and J.W. Noling. 1997. Fumigant alternatives to methyl bromide for polyethylenemulched tomato. HortScience 32:1208-1211.

Locascio, S.J., S.M. Olsen, C.A. Chase, T.R. Sinclair, D.W. Dickson, D.J. Mitchell, and D.O. Chellemi. 1999. Strawberry production with alternatives to methyl bromide fumigation. Proc. Natl. Agr. Plastics Congr. 28:148-154.

Majewski, M.S., M.M. McChesney, J.E. Woodrow, J.H. Prueger, and J.N. Seiber. 1995. Aerodynamic measurements of methyl bromide volatilization from tarped and nontarped fields. J. Environ. Quality 24:742-752.

Mitchell, D.J. and P.A. Rayside. 1986. Isolation, identification, and production of inoculum of Pythium sp., p. 67-70. In: K.D. Dickey (ed.). Methods for evaluating pesticides for control of plant pathogens. Amer. Phytopathol. Soc., St. Paul, Minn.

Nelson, G.O., A.N. Correia, and C.A. Harder. 1976. Respirator cartridge efficiency studies. VII. Effect of relative humidity and temperature. Amer. Ind. Hygene Assn. J. 37:280-288.

Noling, J.W. and J.O. Becker. 1994. The challenge of research and extension to define and implement alternatives to methyl bromide. J. Nematol. 26(Suppl.):573-586.

Riegel, C., D.W. Dickson, L.N. Shaw, and G. Peterson. 2000. Comparison of chisel types, sealing, and application depth on the efficacy of 1,3-dichloropropene in deep sand soils. J. Nematol. (Suppl.) (in press).

Schneider, R.C., R.E. Green, J.D. Wolt, R.K.H. Loh, D.P. Schmitt, and B.S. Sipes. 1995. Dichloropropene distribution in soil when applied by drip irrigation or injection in pineapple culture. Pesticide Sci. 43:97-105.

Trout, T. and H. Ajwa. 1998. Strawberry response to 1,3-D, chloropicrin, and metam sodium applied by drip irrigation systems, p. 12:1-12:2. In: Proc. Annu. Res. Conf. Methyl Bromide Alternatives and Emissions Reductions, Orlando, Fla. 6-8 Nov. Agr. Res. Consulting, Fresno, Calif.

U.S. Department of Agriculture. 1999. Methyl bromide alternatives newsletter. $5(1): 6$.

U.S. Environmental Protection Agency. 1993. Protection of stratospheric ozone. Fed. Reg. 58:15014-15049.

Wang, D. and S.R. Yates. 1998. Methyl bromide emission from fields partially covered with a high-density polyethylene and a virtually impermeable film. Environ. Sci. Technol. 32:2515-2518.

Wang, D., S.R. Yates, F.F. Ernst, J. Gan, and W.A. Jury. 1997. Reducing methyl bromide emission with a high barrier plastic film and reduced dosage. Environ. Sci. Technol. 31:3686-3691.

Yagi, K., J. Williams, N.-Y. Wang, and R.J. Cicerone. 1995. Atmospheric methyl bromide $\left(\mathrm{CH}_{3} \mathrm{Br}\right)$ from agricultural soil fumigations. Science 267:1979-1981.

Yates, S.R., J.Y. Gan, F.F. Ernst, A. Mutziger, and M.V. Yates. 1996a. Methyl bromide emissions from a covered field. I. Experimental conditions and degradation in soil. J. Environ. Quality 25:184-192.

Yates, S.R., J.Y. Gan, F.F. Ernst, A. Mutziger, and M.V. Yates. 1996b. Methyl bromide emissions from a covered field. II. Volatilization. J. Environ. Quality 25:192-202.

Yung, Y.L., J.P.Pinto, R.T. Watson, and S.P. Sander. 1980. Atmospheric bromine and ozone perturbations in the lower statosphere. J. Atmospheric Sci. 37:339353. 